\title{
Life experiences that favor the plenitude and transcendence of the elderly being: a phenomenological-hermeneutical study*
}

\author{
Experiencias de vida que favorecen la plenitud y trascendencia del \\ ser adulto mayor: estudio fenomenológico-hermenéutico \\ Experiências de vida que favorecem a plenitude e transcendência do \\ ser adulto idoso: estudo fenomenológico-hermenêutico
}

How to cite this article:

Guerrero-Castañeda RF, Prado ML, Menezes TMO, Galindo-Soto JA, Ojeda-Vargas MG. Life experiences that favor the plenitude and transcendence of the elderly being: a phenomenological-hermeneutical study. Rev Esc Enferm USP. 2019;53:e03476. DOI: http://dx.doi.org/10.1590/S1980-220X2018029303476

\section{Raúl Fernando Guerrero-Castañeda ${ }^{1}$ \\ Marta Lenise do Prado² \\ Tânia Maria de Oliva Menezes ${ }^{3}$ \\ Jonathan Alejandro Galindo-Soto ${ }^{1}$ \\ Ma. Guadalupe Ojeda-Vargas ${ }^{4}$}

* Extracted from the thesis: "Trascendencia del ser adulto mayor: propuesta fenomenológica de enfermería”, Universidad de Guanajuato, 2017.

${ }^{1}$ Universidad de Guanajuato, Departamento de Enfermería Clínica, Celaya, Guanajuato, Mexico.

2 Universidade Federal de Santa Catarina, Departamento de Enfermagem e Pós-Graduação em Enfermagem, Florianópolis, SC, Brazil.

${ }^{3}$ Universidade Federal da Bahia, Escola de Enfermagem, Salvador, BA, Brazil.

${ }^{4}$ Universidad de Guanajuato,

Departamento de Enfermería y Obstetricia, Celaya, Guanajuato, Mexico.

\section{ABSTRACT}

Objective: To understand the life experiences that favor the plenitude and transcendence of the elderly being. Method: Qualitative study of hermeneutical phenomenological approach. It was conducted from January 2014 to March 2017 in two social groups for seniors. Selection of participants was by intentional sampling with information saturation. Characteristics of participants: men or women aged 60 years and over. Data collection through a phenomenological interview. Study in compliance with the General Law of Health, Subject of Health Research and the Declaration of Helsinki. Analysis through the Heidegger's hermeneutic circle: Pre-understanding, understanding and interpretation. Results: Units of meaning arose. Ontologically, seniors are revealed in their historicity and temporality, emphasize fear and anguish in their daily life, and fall into a feeling of nothing with the need to be authentic that is achieved through care. This understanding of the being is transcendence, and its manifestation is enlightenment. Conclusion: Transcendence is favored by care in the life cycle. Nursing as a science of care can promote actions that facilitate the reach of the encounter of seniors at different stages of their lives.

\section{DESCRIPTORS}

Aged; Geriatric Nursing; Philosophy, Nursing; Hermeneutics.

Corresponding author: 


\section{INTRODUCTION}

International policies on aging ${ }^{(1)}$ highlight the sustained and profound increase in the elderly population worldwide. The society ages as the population grows older than 60 years old. In Mexico, this demographic transition is being experienced together with the challenge of translating the increase of population life expectancy into the experience of years lived with quality ${ }^{(2)}$. A global health policy can favor an active, full, healthy and successful aging.

There are different ways of aging, namely: in the normal old age, there are no disabling physical or psychological illnesses; the pathological old age has different diseases at the organic and/or psychic level that cause disability; and in the successful old age, significant roles in activities that give older adults greater satisfaction and a sense of their existence are performed ${ }^{(3)}$. Aging with plenitude is a focus of study for nursing care, because it can evoke forms of care that potentiate a healthy old age.

The path taken towards plenitude and satisfaction in the old age by exploring the factors that influence this process can express a positive general vision regarding one's aging and the way how each senior experiences it. This is a form of transcendence whose manifestation is plenitude, the capacity for communication, love, joy, active and creative disposition, and the development of their own sense of identity, which are all proper to good aging or successful aging ${ }^{(4)}$.

The experiences of older adults can explore this path, because they are an understanding of human beings in the world, the knowledge resulting from what is observed, done and lived in the world ${ }^{(5)}$ : this is transcendence, the own being understood from him/herself, phenomenologically speaking, it is the being-in-the-world by living the experiences ${ }^{(6)}$. Such experiences may reflect the way in which mature adults or their peers can reach the same end: transcend.

Transcendence is the ultimate goal in the scale of needs ${ }^{(7)}$, it is the culminating personal point beyond self-realization. Logotherapy conceives transcendence as the source and end of the values of life, when an individual has found "meaning" in his/her life and opens up to other worlds, including spiritual ones ${ }^{(8)}$.

In nursing, the self-transcendence term was developed from transcending, which means "going beyond", a "feeling of plenitude" or well-being. The function of nursing is to facilitate this well-being ${ }^{(9)}$ that impacts directly on people and can be promoted by nurses through intervention points ${ }^{(9-10)}$.

Transcendence evokes the understanding of elderly subjects in this moment of their life. There is a search for the meaning that has allowed seniors to achieve that plenitude throughout their history and make them who they are today ${ }^{(11)}$. The path becomes viable through the historicity of the person, the path traveled by the transcendent senior and by focusing on the characteristics and knowledge about the way the path was conducted during one's history. Heidegger's phenomenology deals with transcendence as an understanding of the historicity and temporality of the being. The path through Heidegger's phenomenology is relevant for understanding this phenomenon from the point of view of elderly individuals throughout their lives.

Thus, the nurse can propose prevention models and care actions to seniors, not only at this stage but from different stages of life in order to reach plenitude in aging(6,11). The objective of this study was to understand the life experiences that favor the plenitude and transcendence of seniors.

\section{METHOD}

TyPe OF STUdy

Phenomenological-hermeneutic qualitative study based on Martin Heidegger's concepts.

\section{SCENARIO}

It was conducted in two groups of senior citizens, namely: a day house center (Casa Día) and a retirees association where they meet every week. During four months (May-August 2016), the scenario was approached informally by the main researcher, who got involved in activities with the elderly subjects and engaged in informal conversations to establish empathy with them. The seniors visit the day house center to attend various workshops, and the retirees association has various activities, among which the care of a garden in a school. Seniors get involved in both groups in order to have a social life together and perform various activities.

\section{CRITERIA FOR SELECTING THE PARTICIPANTS}

Participants were male and female adults aged 60 years and older, who reported feeling plenitude when the scenario was approached. They were asked the following question: Do you have a feeling of plenitude at this stage of your life? According to the literature reviewed, plenitude is a consequence of transcendence and this was understandable for participants. Exclusion criteria were: seniors who reported no feelings of plenitude and those with verbal communication difficulty. Subjects who answered affirmatively, were invited to participate in the study, the phenomenological interview was performed and the informed consent was read. Upon achieving the theoretical saturation of information, 11 participants were selected. After completing all interviews, a careful listening was performed and through the theoretical sensitivity of the researcher the converging units of meaning that emerged and provided an explanatory scheme of the phenomenon were determined. Five seniors reported the feeling of plenitude but did not want to participate and 15 said they did not have feelings of plenitude in their old age. Participants were assigned fictitious names in Sanskrit to ensure anonymity.

\section{Data Collection}

Phenomenological interviews were conducted; in the day house center, a comfortable place to perform them was provided, and in the retirees association, they were performed at the homes of participants as per the group's request, because they felt comfortable and confident that way. Participants were asked the initial question ${ }^{(12)}$ : Tell me, what experiences of your life favor that nowadays you feel plenitude at this stage of your life? 
The phenomenological interview is a social encounter in which there is a conjunction of mutual perceptions through empathy and intersubjectivity ${ }^{(13-14)}$ for building knowledge about the interviewee's perceptions regarding the human being located in the world. Thus, "what one asks in the developed question is the being (...) what is asked, the sense of being, a peculiar repertoire of concepts (...) what is asked in the question that interrogates by the own entities"(6). Interviews were audio-recorded, conducted by the principal investigator, and lasted an average of 70 minutes (minimum of 50 minutes and maximum of 2 hours 20 minutes).

\section{ANALYSIS AND PROCESSING OF DATA}

The transcription and initial analysis were performed in Word 2016 on the same day of the individual interview to rescue the units of meaning. In January 2017, interviews were sent to participants, who validated and returned them. A new ontological analysis was performed with involvement of all researchers. The construction of data from discourses was based on Heidegger's Hermeneutic Circle $^{(6,15)}:$ 1) Pre-understanding, 2) Understanding and 3) Interpretation.

\section{ETHICAL ASPECTS}

The ethical principles established in the General Law of Health in Research were followed ${ }^{(16)}$. The study was approved by the Research Committee of the CelayaSalvatierra Campus, Universidade de Guanajuato under number CIDSC-2560519. Participants signed the informed consent form.

\section{RESULTS}

Table 1 shows the characterization of participants.

The units of meaning are constructed based on key linguistic elements for understanding the phenomenon. They constitute the first moment of the hermeneutic circle (phenomenological reduction), describe the phenomenon not yet revealed, and provide a vague and median pre-understanding ${ }^{(6,17)}$. After reading the discourses, the following seven units of meaning emerged:
1. The Being in fear: the adversity. Seniors have recognized experiences in their lives that they identified as threatening. They searched for ways to alleviate them by identifying threats. This was reflected in problems with the partner, physical, verbal, psychological abuse, and abandonment. As expressed in the following speech:

(...) the thing is that small jealousy issues started and they got bigger (...) to the degree that I stopped going to the supermarket, when I was going to have my haircut, dye my hair, have my nails done I had to take my son along, then, one cannot live like that, he started taking out my things, papers, I do not have (...) (Omana).

Participants recognize they face this type of critical situations in different ways. They used strategies to tackle diverse situations such as by confronting and planning to try to resolve the matter.

2. The Being before painful experiences and anguish. Seniors also reported painful experiences they did not choose, but appeared throughout their lives. In that movement of temporality and by knowing how to face such situations, they shaped their current configuration. They recognize each fall has possibilities that have made them decide to stand up and move forward, as expressed in the following speech:

(...) for me, the loss of my mother was the most painful and most difficult thing, although I fought and did not fight in vain but I think I did what I could (...) All those things that happened to me were those that made me reflect and why I wanted to be (...) (Vani).

3. The Being with a consciousness of finitude and death. Elderly individuals identify their bodily finitude, identify that life has an end, prepare for it and connect with themselves for that moment, manifest impetus to move forward and serenity without fear of physical death. As stated in the speech:

(...) God allows me to live, I do not know how much longer I will live, according to the circumstances (...) I try to understand, comprehend, I do not consider myself bad, but I am not perfect either (...) God gave me life to try to be happy and make those around me happy, if I am with someone who is also happy and not be negative (...) (Ura).

Table 1 - Characterization of participants - Celaya, Gto, Mexico, 2017.

\begin{tabular}{|c|c|c|c|c|c|c|}
\hline Name & Age /sex & Education & Work & Pensioner & Lives with & Religion \\
\hline Omana (Beginning of life) & $74 \mathrm{~F}$ & Bachelor's degree & Employee & No & Alone & Catholic \\
\hline Vidya (Knowledge) & $74 \mathrm{~F}$ & Bachelor's degree & Retired & Yes & Son & Catholic \\
\hline Madhavi (Spring) & $70 \mathrm{~F}$ & Bachelor's degree & Home & Yes & Alone & Catholic \\
\hline Reva (He who moves) & $63 \mathrm{~F}$ & Primary & Home & Yes & Alone & Christian \\
\hline Naidu (Protector) & $63 \mathrm{~F}$ & Bachelor's degree & Retired & Yes & Alone & Catholic \\
\hline Ura (Heart) & $63 \mathrm{~F}$ & Bachelor's degree & Retired & Yes & Son & Catholic \\
\hline Muni (Disinterest) & $74 M$ & Bachelor's degree & Retired & Yes & Wife & Catholic \\
\hline Saati (Longevity) & $78 \mathrm{~F}$ & Secondary & Home & Yes & Daughter & Catholic \\
\hline Vani (Eloquence) & $64 \mathrm{~F}$ & Secondary & Home & No & Daughter & Catholic \\
\hline Nayat (Leader) & $60 \mathrm{H}$ & Engineering & Retired & Yes & Wife & Catholic \\
\hline Karuna (Compassion) & $60 \mathrm{~F}$ & Technician & Retired & Yes & Son & Catholic \\
\hline
\end{tabular}


Death is also conceived as finitude, a process of life: for the elderly, loneliness, sadness, and emptiness are a kind of "being dead". In other words, there is no existence and seniors conceive the process of corporeal death by assimilating it as an existential emptiness. Some speak of being reborn, as the participant reports:

(...) I am not sure I have nothing to do anymore, but I say: I have reached this age, there is nothing ahead, but there is always going to be something abead (...) (Omana).

4. The consciousness of a higher power for the transcendence of the being. Elderly subjects recognize the presence of a higher power in their lives by calling it God. They recognize God has helped them throughout their lives, and sustains their steps, maintains their lives, gives them stability and strength, health, well-being, and is a superior force that has accompanied them. As expressed in the following speeches:

(...) it was very heavy but thank God, that is why I say that you feel plenitude because you got what you wanted, there was a lot of help, spiritual help, and from then on, I carried on preparing myself (...) (Vidya).

(...) I know God, I am quite sure about it, because a leaf of a tree does not move if it is not by His will, and it is good and I feel blessed (...) (Reva).

5. The Being-with the family and coexisting in a group. Seniors identify the presence of the family and recall that the family foundation was built upon the promotion of values, beliefs and teachings about self-care. They also highlight the example of parents and those who perceive absences or negative aspects of the family, which have allowed them to reach transcendence. Similarly, they recognize the coexistence with children and grandchildren is important for feeling good. As shown in the following testimony:

(...) thank God who gave me my granddaughters, who gave me my daughter and I am happy with them (...) when my daughter was born, it was the most beautiful thing God gave me, a divine gift when my daughter, I do not know (...) I felt plenitude, fully happy, really satisfied, every time my granddaughters were born, I felt plenitude, happy, satisfied (...) (Naidu).

(...) I like to talk with the grandchildren, I have to give them examples of simple readings (...) (Muni).

Seniors relate the importance of group coexistence with other seniors. Sometimes these groups offer the strength to recover self-esteem and overcome losses. By participating in a group, they live with others, travel with them, and feel the affection, which generates a sense of satisfaction. Relationships with their peers give them a sense of identification and support beyond family ties. The following speech demonstrates these feelings:

(...) right now I am participating in two civil associations of active and positive women, we have meetings, we go for a walk, we have coexistence, it is very beautiful (...) I feel plenitude with that and I am very happy (...) (Naidu).
6. The Being as Care: occupation, concern and solicitation of the other. Seniors conceive themselves as beings who take care of their physical health. That care goes back as part of having done over time, what they continue to do for keeping the good health. Seniors stated having good habits from childhood that they preserve to this day by taking care of their diet and practicing physical activity such as walking and yoga. As shown in the following speech: (...) remember your diet (...) look, I have a low fat, low salt, low sugar diet and that's it, and it has been this way since childhood (...) you know that every time I go to the doctor, well, almost never, only as right now, I have a medical examination (...) (Vani).

Seniors reflect self-care in relation to personal habits of healthy eating and physical exercise. In addition, seniors show spiritual and religious care, as put by Karuna:

(...) I went back to the Catholic group a year ago (...) I am very happy because we dance and praise God with songs, and I also like that a lot (...) (Karuna).

Sometimes, seniors take care of others. This can be the product of different situations, some as part of the family relationship with the caregiver. Some participants who spoke of these forms of caring for the other expressed the following:

(...) right now my mother has senile dementia, so, every eight days, I take care of her for one day ... I feel very happy taking care of my mother (...) (Naidu).

(...) I can tell you, everything I did was for my children, work for the children, take care of them (...) (Sati)

Caring is a way of understanding oneself as a human being of care projected in the space towards others in an intimate relationship with the other. Care is born from human beings and expands as a reflection of the human sense.

7. Life project as a search for authenticity. When seniors got caught up in everyday routine, they felt a lack of meaning, and saw themselves in an inauthentic situation, as well as lack of opportunities to study and accommodation to daily routine. Seniors refer they seek to reach their goals, set challenges for the future and seek to achieve them, as expressed in the following speech:

(...) at the beginning of my life, the only aspiration was to be a bricklayer, have eight children, a brick house and even there, a bicycle and that was it (...) I had the strength to say I can do it, I can get ahead, I can be a professional, I can serve my fellow individuals (...) (Nayat).

This possibility of choosing their path and orienting themselves towards their own meaning has been approached from the existentialist perspective as a will of meaning: the intrinsic motivation of human beings to orient themselves towards the meaning of their life guided by personal freedom.

When taking care of themselves and proposing a life project, seniors have gone through a series of goals with meanings that gives them satisfaction, encounter with themselves, identification of their strengths, personal acceptance, 
and an authenticity that generates freedom. The following speeches manifest these aspects:

(...) that helped me, I do not know if it arose my feelings, my courage was everything, yes, I do not know if everything was mixed and it made me strong, it made me decisive because I decided to do something, to be someone (...) yes, from that moment, I said I have to be someone (...) (Vani).

(...) I had to forgive many people and the main one: forgive myself (...) to be right now where I am, but what is helping me to reach my plenitude, my emotional maturity, is truly helping me to recover (...) (Karuna).

These discourses are linked to the life purpose connected to the meaning that seniors sought and continue to seek. Seniors seek to reach goals and grow, develop themselves and feel authentic and proper to themselves in the sense of being who they want to be.

Thus, seniors are aware of their passage through life, recognize their trajectory: a historicity that makes them feel plenitude, unique and marked by a series of temporary events. However, these sometimes threatening events such as suffering and pain, make them experience emptiness and a feeling of void. This temporality has shaped who they are today, they recognize that falls in diverse situations have made them strong in a way that, at this stage, they recognize a feeling of plenitude, joy and satisfaction, as expressed by the following participants:

(...) I tell you, regardless of the physical aspect, because I am fine, thank God, because I feel plenitude (...) (Omana).

(...) I started with the fact that they detected "sugar", and I have been hypertensive for many years, but it was there (...) I say that I am very well (...) now, it has been two years and I am going on trips alone, and I feel plenitude, I feel quite well (...) (Reva).

(...) because it is a matter of trying to get ahead against the wind and the tide, there was a moment when I sank, but I went ahead and this is why I tell you that yes, I believe I am a person in plenitude (...) (Madhavi).

Seniors have used care as a basis to understand their history of life and what is happening to them. Care is multidimensional and despite the negative stereotypes surrounding the old age, seniors have shown positive aspects at this stage and the approximation of feelings of well-being, plenitude and self-acceptance.

\section{DISCUSSION}

The transcendence of seniors is visible through temporality and specific moments throughout the life history of a person. Therefore, the transcendence is continuous, infinite and constantly repeated throughout life.

These moments of temporality constitute the everyday life of the being, continuous events manifested in a time slot, where seniors immersed in everyday life often face challenging situations, moments that break the authenticity of their being, where fear appears before the unknown, threatening or sad situations, mourning and losses. Everything presents as a challenge to be solved, then fear appears, and seniors detect this threatening situation and can choose between several possibilities.

The 'fear of', as 'the fear that' always 'opens' (...) and with equal originality of intramundane entities in their threatening being and the "being" in their 'threatened being"' ${ }^{(6)}$. The elderly felt stunned by various situations that challenged their worth in the world and gave them a perspective that their life was inauthentic and meaningless. Traumatic or negative events throughout seniors' lives may favor the onset of depressive symptoms in adulthood due to lack of support ${ }^{(18)}$ so, they reported feeling threatened in various moments.

Although any possibility of recovering authenticity is valid, seniors probably tried several possibilities, namely managing to face the threatening situations, actively coping when controlling the situation, positive feelings towards the resolution of the threat, resorting to social support and reintegration with the family, spiritual support, and professional emotional support ${ }^{(19)}$. When seniors experienced something threatening or an event they could not control, the feeling of anguish began, an emptiness from the threatening situation that lacks meaning because something is not working well and distresses them. However, they reckon losses provide courage before life, and allow a vision, because "the feeling of anguish originally and directly opens up the world as a world (...) the anguish as a way of being, for the first time, opens up the world as a world"(6). Thus, by feeling anguished, seniors recognize the moment they must do something to get out of their anguish and find the way to well-being.

At this moment, anguish makes the elderly feel empty and experience the fall, realize their humanity and vulnerability to the various painful and fearsome situations. Seniors are part of the world, and while some manifest a feeling of devastation, others simply see learning opportunities offered by life, but above all, there was a fall before each painful event.

Falls are a way of absorbing oneself in the world, not finding a way out and not finding the meaning of life in itself, the "being there" is always immediately the "fallen" of oneself as properly "being able to be" and "fallen" in the "world". The state of "fallen" in the "world" shows the absorption in the "being one with the other"(6).

In the falls, the nothingness is lived, being perhaps the most critical moment, because it is where the possible beginning is experienced. The situation can continue, and if it continues, seniors will be inauthentic because they will not find a meaning to what was lived: pain, physical death, mourning, illness, violence, abandonment; many situations that challenged their sense of life, and brought feelings of nothingness, emptiness, non-existence. The fall moves them as "the fall is not limited to being an existential determination of 'the being in the world". The whirlwind makes the character of the "state of movement" clear ${ }^{(6)}$. 
The fall has helped seniors to find themselves, since in the nothing, the encounter with the world is rediscovered, as they see the need to do something to end that situation and be able to feel authentic. Then, they have the sense of death and finitude, death of the anguishing situation, the nothing and the possibility of an opening to new opportunities. Seniors recognize death as finitude and "by dying is shown the ontological constitution of death by the "being in each case"(6), and as finding themselves, death comes to reconsider a new beginning.

Aging is related to the process of dying because it is the last stage of human beings, after which comes the decline and death. However, in this study, the association of death with the last stage of life ${ }^{(20)}$ takes the meaning of something that comes to an end: finitude. From a philosophical perspective, death becomes an encounter, where the human being dies in the sense of completing a phase, a stage or a cycle. Therefore, death is closer to the process of multiple deaths in a single life, it is an experience to re-emerge again, a new world of opportunities ${ }^{(21)}$.

All processes die, end and thus, one will get out of that inaunthenticity that led to the fall and nothingness. The beings realize their fact, that is, they have the intention of being who they want to be and choose among the possibilities given by the world. From there, they resort to what surrounds them, because "what is ready-to-hand in our everyday dealings has the character of closeness" ${ }^{(6)}$. They take that closeness as their own and make it possible through actions performed to get out of the feeling of nothingness; what they require, they find in their near world.

Everything at the hand of beings that they make their own for overcoming nothingness is called care. Care is a cure, because it restores the inauthenticity of the being, the care cures the empty and fallen being and manifests in their daily life, where "are inherent forms of occupation or cure that allow the entities that 'heal' to face in such a way that the 'multiformity' of the intramundane becomes visible" ${ }^{(6)}$.

The care as a cure is an action exercised by the being. Everything is done in search of a sense or meaning of life, a meeting with oneself that allows one to feel authentic again, give a new understanding to the being. In a superficial way, the concern is what seniors did for themselves, as "ontologically, all men's ways of behaving are transposed from 'cure' and guided by a surrender to something”"(6). The surrender will be to themselves in order to understand the world and be able to feel plenitude.

The care is part of the being when appears the intention to exercise it, which leads one to want to cure those fallen by fear. Thus, care can be promoted and is multidimensional, since it involves the physical care expressed as a Solicitude, the self-care, and "even concern with food and clothing, and the nursing of the sick body, are forms of 'solicitude' (6). This is the first care for self-cure; one's self-care. Physical care is a sense of searching for the bodily well-being that also manifests in spiritual care through spirituality and religion, a sense of connection related to the theory of gerontotranscendence, which comprises the communion with the cosmic.
Spirituality is a type of connection that increases in the last stage of life or the old age, in which is found a relationship of the sacred in the spirituality conceptualized as God by seniors ${ }^{(22-23)}$. Phenomenologically, spirituality is based on human beings experience of attaining the feeling of plenitude. Thus, "the main phenomenon is the faith in being able to obtain the presence of God, with what is also jointly given in principle, the ethical imperative (...) the original religiosity consists of the factual experience of life" (24).

Care is also expressed in the care of being together with others and doing for others. The care for oneself is found in one's own family. Seniors reflect a constant bond with their family throughout life, and the family becomes a resource for self-cure, where there is protection and cure. The family focuses on a mechanism of teaching, love, protection and care $^{(25)}$ and grants resources to each member that allow them to be who they are inside and outside of the family.

In addition, seniors use the care in social support as part of their emotional growth. It can be found in social groups, where friendships flourish, and similar events are experienced such as losses, characteristics and facts with people going through the same stage of life ${ }^{(26)}$.

The care for the other becomes a reflection of personal care $^{(27)}$. The care of everything as a whole, care as a cure of the world of being-there, where beings live and experience their daily life must also be cured, and reflects the being's intention to see their sense of authenticity and life reflected.

Care as a cure expands as a phenomenon of projection of beings, and the need that their nothing becomes a sense of life and shares it. Beings are a being-with, and open themselves to others in the world in order to heal themselves, "this own 'open state' modifies with equal originality the 'uncovered state' of the 'world' founded on them and the 'open state' of the 'being there with' of others" ${ }^{\prime \prime)}$.

Every care action is composed of a need to come out of nothing, a need to find a meaning that leads them to understand the situation they went through from the beginning. This understanding is the transcendence of the being; when subjects take care of themselves, of others, and of their environment, they take care of their whole and remain factual. In other words, they have a purpose, which is to come out of nothing, seek and find a meaning to their existence, their temporal experiences and conform their historicity.

Human beings are constantly searching for their purpose in life, and this is a component of human well-being in the psycho-emotional sphere. The life purpose is a resource employed by human beings, where a goal is fixed and actions taken towards it are guided by a meaning of their purpose ${ }^{(28)}$.

Understanding adverse situations and choosing possibilities for self-care and self-cure reflect the transcendence of seniors throughout life. Resilient seniors seek to adapt positively to adverse situations by overcoming stress and living satisfactorily after adversity ${ }^{(29)}$. Transcendent seniors allow themselves to understand the authenticity and experience plenitude with freedom and no ties. 
Therefore, the transcendence of beings is their essential structure, is the understanding of 'why' and 'what for' of their lives, "only from the transcendence emerges the comprehensive articulation of the being" (11). The understanding of their meaning leads them to take care of themselves to heal themselves from nothing, and provides a feeling of well-being and plenitude after adversities that led them to the fall. This sensation enlightens the beings. Such enlightenment was achieved through care, since care as a cure is the foundation of the beings' understanding in order to feel plenitude. When the beings feel plenitude, they are said to be enlightened beings, transcendent beings.

By understanding their sense of life, "out of oneself, from ecstasies of becoming, the gone and the present, is the condition of possibility that one is an entity existing as his/her 'there' (...) is an enlightened being”' ${ }^{(6)}$. Thus, the beings are transcendent throughout their life through moments in their temporality. Transcendence is the manifestation of seniors existence by recognizing their past, present and future, where lie possibilities of understanding a sense of life and finding fulfillment after the continual threatening situations.

Care is the basis of finding the sense of plenitude. As the discipline of care, nursing can intervene in various ways of caring, from the promotion of physical and spiritual self-care, by teaching, healing, and caring for the other.In nursing, the goal of care would be to help seniors understand the meaning of what happens to them and that it guides their actions towards achieving enlightenment, plenitude, wholeness and satisfaction.

Nurses must understand that their gerontological work deals with seniors as whole human beings ${ }^{(30)}$ with a history of life that has built a historicity of themselves. The care has based the understanding of a sense of life of seniors to this day in their old age. Nursing can address the temporal moments of beings and explore how they have developed their own understanding in order to feel plenitude, thus being able to transfer the care to others. Transcendence is a phenomenon that can be addressed theoretically. In practice, it can generate models of care that promote the understanding of life in various situations.

The relevance of this study lies in the fact of exploring how the elderly report their plenitude in order to comprehensively construct a phenomenological approach to transcendence and plenitude. This allows the discussion of existing theories and philosophies regarding transcendence and how nurses can be involved in them. The possible limitations are the nongeneralization of results, although this limitation becomes strength as they can be transferred to other scenarios.

\section{CONCLUSION}

Transcendence is the result of a process of understanding the being. Seniors understand their own being in a sense of totality, and it is possible to unravel the process of transcendence of each event manifested in their lives.

Care is multidimensional and the essence of transcendence of beings, so they take care of themselves, of others, of their world and of everything. Care sustains the existence, because being action is manifestation and manifestation is existence. Nursing exercises, promotes and lives the care, and can promote it for the transcendence of seniors, since transcendence is a process throughout life. In old age, it can be reinforced and promoted with a strong care base throughout the life cycle.

\section{RESUMEN}

Objetivo: Comprender las experiencias de vida que favorecen la plenitud y trascendencia del ser-adulto mayor. Método: Estudio cualitativo con enfoque fenomenológico hermenéutico. Se llevó a cabo de enero 2014 a marzo 2017 en dos grupos de convivencia de adultos mayores. Selección de participantes por muestreo intencional con saturación de información. Características de participantes fueron: tener 60 años y más, hombres o mujeres. Recolección de datos mediante entrevista fenomenológica. Cumplió con la Ley General de Salud, Materia de Investigación en Salud y la Declaración de Helsinki. Análisis a través del círculo hermenéutico heideggeriano: Pre-comprensión, Comprensión e Interpretación. Resultados: Ónticamente surgieron unidades de significado. Ontológicamente el ser-adulto mayor es desvelado en su historicidad y temporalidad, destacando en su cotidianidad el temor y angustia, cayendo en un sentimiento de nada con necesidad de ser auténtico, logrado a través del cuidado; esta comprensión del ser es trascendencia cuya manifestación es la iluminación. Conclusión: La trascendencia se favorece con cuidado en el ciclo vital, enfermería como ciencia del cuidado puede promover acciones que faciliten alcanzar el encuentro del ser-adulto mayor en diferentes etapas de su vida.

\section{DESCRIPTORES}

Anciano; Enfermería Geriátrica; Filosofía en Enfermería; Hermenéutica.

\section{RESUMO}

Objetivo: Compreender as experiências de vida que favorecem a plenitude e transcendência do ser-adulto idoso. Método: Estudo qualitativo com enfoque fenomenológico-hermenêutico. Foi realizado de janeiro de 2014 a março de 2017 em dois grupos de convivência de idosos. Seleção de participantes por amostragem intencional com saturação de informação. Ás características dos participantes foram: ter 60 anos ou mais, homens ou mulheres. Coleta de dados por meio de entrevista fenomenológica. Foi cumprida a Lei Geral da Saúde, Matéria de Pesquisa em Saúde e a Declaração de Helsinki. Análise por meio do círculo hermenêutico heideggeriano: Pré-compreensão, Compreensão e Interpretação. Resultados: Onticamente surgiram unidades de significado. Ontologicamente o ser-adulto idoso é revelado na sua historicidade e temporalidade, destacando na sua cotidianidade o temor e a angústia, caindo em um sentimento de nada com necessidade de ser autêntico, obtido por meio do cuidado; essa compreensão do ser é transcendência, cuja manifestação é a iluminação. Conclusão: A transcendência é favorecida com o cuidado no ciclo vital; a enfermagem como ciência do cuidado pode promover ações que facilitem o encontro do ser-adulto idoso em diferentes etapas da sua vida.

\section{DESCRITORES}

Idoso; Enfermagem Geriátrica; Filosofia em Enfermagem; Hermenêutica. 


\section{REFERENCES}

1. Organización Mundial de la Salud. Informe mundial sobre el envejecimiento y la salud. Ginebra: OMS; 2015.

2. Klein A. De la ancianidad al adulto mayor. Desacatos [Internet]. 2016 [citado 2016 oct. 17];50:156-69. Disponible en: http://www.redalyc. org/pdf/139/13943562011.pdf

3. Limón Mendizábal MR. Envejecimiento activo. Crítica [Internet]. 2015 [citado 2016 oct. 17];(998):22-7. Disponible en: http://www. revista-critica.es/2015/09/10/el-envejecimiento-activo/

4. McCarthy VL, Bockweg A. The role of transcendence in a holistic view of successful aging: a concept analysis and model of transcendence in maturation and aging. J Holist Nurs. 2013;31(2):84-92. DOI: http://dx.doi.org/10.1177/0898010112463492

5. Minayo MCS. Los conceptos estructurantes de la investigación cualitativa. Salud Colect [Internet]. 2010 [citado 2016 oct. 17];6(3):251-61. Disponible en: http://www.scielo.org.ar/scielo.php?script=sci_arttext\&pid=S1851-82652010000300002

6. Heidegger M. El ser y el tiempo. México: Fondo de Cultura Económica; 2015.

7. Frager R, Fadiman J. Teorías de la personalidad. 6ª ed. México: Alfaomega; 2010.

8. Frankl V. Psicoanálisis y existencialismo. México: Fondo de Cultura Económica; 2014.

9. Reed P. The Theory of self-transcendence. In: Smith MJ, Liehr PR, editors. Middle range theory for nursing. New York: Springer; 2013. p. 109-40.

10. Haugan G, Moksnes UK, Løhre A. Intrapersonal self-transcendence, meaning-in-life and nurse-patient interaction: powerful assets for quality of life in cognitively intact nursing-home patients. Scand J Caring Sci. 2016;30(4):790-801. DOI: http://dx.doi.org/10.1111/ scs. 12307

11. Heidegger M. Principios metafísicos de la lógica. Madrid: Síntesis; 2007.

12. Gil AC, Yamauchi NI. Elaboração do projeto na pesquisa fenomenológica em enfermagem. Rev Baiana Enferm. 2014;26(3):566-73. DOI: http://dx.doi.org/10.18471/rbe.v26i3.6613

13. Paula CC, Padoin SMM, Terra MG, Souza IMO, Cabral IE. Modos de condução da entrevista em pesquisa fenomenológica: relato de experiência. Rev Bras Enferm. 2014;67(3):468-72. DOI: http://dx.doi.org/10.5935/0034-7167.20140063

14. Guerrero-Castañeda RF, Menezes TMO, Ojeda-Vargas MG. Características de la entrevista fenomenológica en investigación en enfermería. Rev Gaúcha Enferm. 2017;38(2):e67458. DOI: http://dx.doi.org/10.1590/1983-1447.2017.02.67458.

15. Kempfer SS, Prado ML, Sebold LF, Girondi R. A hermenêutica heideggeriana como fonte de dados em um estudo fenomenológico. Atas CIAIQ2015 [Internet]. 2015 [citado 2016 nov. 1]:108-12. Disponível em: http://proceedings.ciaiq.org/index.php/ciaiq2015/article/ viewFile/25/24

16. México. Secretaria de Salud. Reglamento de la Ley General de Salud en materia de investigación para la salud: los aspectos éticos de la investigación en seres humanos [Internet]. México: SSA; 2014 [citado 2017 sep. 30]. Disponible en: http://www.salud.gob.mx/unidades/ cdi/nom/compi/rlgsmis.html

17. Heidegger M. Marcas do caminho. Petrópolis: Vozes; 2008.

18. Gameiro GR, Minguini IP, Alves TCTF. O papel do estresse e de acontecimentos cotidianos para o desenvolvimento da depressão na terceira idade. Rev Med. 2014;93(1):31-40. DOI: http://dx.doi.org/10.11606/issn.1679-9836.v93i1p31-40

19. Rajaei AR, Khoynezhad GR, Javanmard J, Abdollahpour M. The relation between positive psychological states and coping styles. J Fundam Ment Heal [Internet]. 2016 [cited 2016 Nov 5];18(1):57-63. Available from: http://eprints.mums.ac.ir/2184/2/JFMH_Volume\%2018_ Issue\%201_Pages\%2057-63-2.pdf

20. Anjos D, Silva EAA, Santos JM, Oliveira SCF, Saldanha AAW. Um olhar qualitativo sobre a percepção de finitude na terceira idade. Indagatio Didact [Internet]. 2013 [citado 2016 set. 22];5(2):1-17. Disponível em: http://revistas.ua.pt/index.php/ID/article/view/2459/2330

21. Menezes TMO, Lopes RLM. Significados do vivido pela pessoa idosa longeva no processo de morte/morrer e luto. Ciênc Saúde Coletiva. 2014;19(8):3309-16. DOI: http://dx.doi.org/10.1590/1413-81232014198.05462013

22. Jewell AJ. Tornstam's notion of gerotranscendence: re-examining and questioning the theory. J Aging Stud. 2014;30:112-20. DOI: http:// dx.doi.org/10.1016/j.jaging.2014.04.003

23. Zenevicz L, Moriguchi Y, Madureira VSF. The religiosity in the process of living getting old. Rev Esc Enferm USP [Internet]. 2013 [cited 2017 Sept 30];47(2):433-9. Available from: http://www.scielo.br/scielo.php?script=sci_arttext\&pid=S0080-62342013000200023\&lng=p t\&nrm=iso\&tlng=en

24. Heidegger M. Fenomenologia da vida religiosa. Petrópolis: Vozes; 2010.

25. Alanen L. Repensando a infância, com Bourdieu. Rev NUPEM [Internet]. 2014 [citado 2016 set. 26];6(11):39-55. Disponível em: http:// www.fecilcam.br/revista/index.php/nupem/article/view/588

26. Emma S, Valdés C. El apoyo y la convivencia como predictores de bienestar en la vejez. Rev Kairós [Internet]. 2011 [citado 2016 sep. 22];14(1):2176-901. Disponible en: http://revistas.pucsp.br/index.php/kairos/article/viewFile/6925/5017

27. Amorim, KPC. O cuidado de si para o cuidado do outro. Rev Bioethikos [Internet]. 2013 [citado 2016 set. 30];7(4):437-41. Disponível em: http://www.saocamilo-sp.br/pdf/bioethikos/155557/a09.pdf 
28. Heintzelman SJ, King LA. Life is pretty meaningful. Am Psychol. 2014;69(6):561-74. DOI: http://dx.doi.org/10.1037/a0035049.

29. Alfonso J, López P. Un análisis crítico del concepto de resiliencia en psicología. An Psicol. 2015;31(3):751-8. DOI: http://dx.doi. org/10.6018/analesps.31.3.185631

30. Polaro SHI, Gonçalves LHT, Alvarez AM. Building the gerontological performance of nurses in Family Health Programs. Rev Esc Enferm USP [Internet]. 2013 [cited 2016 Sept 30];47(1):160-7. Available from: http://www.scielo.br/scielo.php?script=sci_arttext\&pid=S0080$62342013000100020 \& \operatorname{lng}=\mathrm{en} \& \mathrm{nrm}=\mathrm{iso} \& \operatorname{lng}=\mathrm{en}$

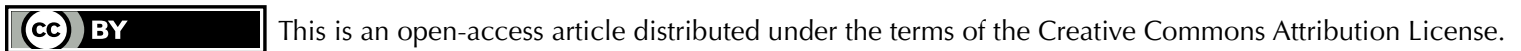

